University of Nebraska - Lincoln

DigitalCommons@University of Nebraska - Lincoln

2009

\title{
Uranium Speciation As a Function of Depth in Contaminated Hanford Sediments - A Micro-XRF, Micro-XRD, and Micro- And Bulk-XAFS Study
}

\author{
David Singer \\ Stanford University, dmsinger@berkeley.edu \\ John M. Zachara \\ Pacific Northwest National Laboratory, john.zachara@pnl.gov \\ Gordon Brown \\ Stanford University
}

Follow this and additional works at: https://digitalcommons.unl.edu/usdoepub

Part of the Bioresource and Agricultural Engineering Commons

Singer, David; Zachara, John M.; and Brown, Gordon, "Uranium Speciation As a Function of Depth in Contaminated Hanford Sediments - A Micro-XRF, Micro-XRD, and Micro- And Bulk-XAFS Study" (2009). US Department of Energy Publications. 238.

https://digitalcommons.unl.edu/usdoepub/238

This Article is brought to you for free and open access by the U.S. Department of Energy at DigitalCommons@University of Nebraska - Lincoln. It has been accepted for inclusion in US Department of Energy Publications by an authorized administrator of DigitalCommons@University of Nebraska - Lincoln. 
Uranium Speciation As a Function of Depth in Contaminated Hanford Sediments - A Micro-XRF, Micro-XRD, and Micro- And Bulk-XAFS Study

\author{
DAVID M. SINGER, *, †, " \\ JOHN M. ZACHARA, ${ }^{\ddagger}$ AND \\ GORDON E. BROWN JR ${ }^{\dagger, \S}$ \\ ${ }^{1}$ Surface and Aqueous Geochemistry Group, Department of \\ Geological and Environmental Sciences, Stanford University, \\ Stanford, California 94305-2115, Fundamental Sciences \\ Directorate, Pacific Northwest National Laboratory, Richland, \\ Washington 99354, and Stanford Synchrotron Radiation \\ Lightsource, SLAC, MS 69, 2575 Sand Hill Road, \\ Menlo Park, California, 94025
}

Received July 28, 2008. Revised manuscript received December 2, 2008. Accepted December 3, 2008.

The distribution and speciation of $\mathrm{U}$ and $\mathrm{Cu}$ in contaminated vadose zone and aquifer sediments from the U.S. DOE Hanford site (300 Area) were determined using a combination of synchrotron-based micro-X-ray fluorescence ( $\mu \mathrm{XRF}$ ) imaging, micro-X-ray absorption near edge structure ( $\mu$ XANES) spectroscopy, and micro-X-ray diffraction ( $\mu \mathrm{XRD}$ ) techniques

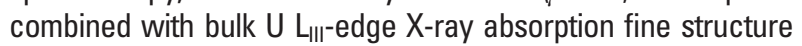
(XAFS) spectroscopy. Samples were collected from within the inactive North Process Pond (NPP2) at $8 \mathrm{ft}$ (2.4 m, NPP2-8) depth and $12 \mathrm{ft}$ (3.7 m, NPP2-12) depth in the vadose zone, and fines were isolated from turbid groundwater just below the water Table (12-14 ft, $\sim 4 \mathrm{~m}, \mathrm{NPP} 2-\mathrm{GW})$. $\mu \mathrm{XRF}$ imaging, $\mu \mathrm{XRD}$, and $\mu \mathrm{XANES}$ spectroscopy revealed two major $\mathrm{U}$ occurrences within the vadose and groundwater zones: (1) low to moderate concentrations of $\mathrm{U}(\mathrm{VI})$ associated with finetextured grain coatings that were consistently found to contain clinochlore (referred to here as chlorite) observed in all three samples, and (2) U(VI)-Cu(II) hotspots consisting of micrometer-sized particles associated with surface coatings on grains of muscovite and chlorite observed in samples NPP2$8^{\prime}$ and NPP2-GW. In the aquifer fines (NPP2-GW), these particles were identified as cuprosklodowskite (cps:

$\left.\mathrm{Cu}\left[\left(\mathrm{UO}_{2}\right)\left(\mathrm{SiO}_{2} \mathrm{OH}\right)\right]_{2} \cdot 6 \mathrm{H}_{2} \mathrm{O}\right)$ and metatorbernite (mtb: $\left.\mathrm{Cu}\left(\mathrm{UO}_{2}\right)_{2}\left(\mathrm{PO}_{4}\right)_{2} \cdot 8 \mathrm{H}_{2} \mathrm{O}\right)$. In contrast, the $\mathrm{U}-\mathrm{Cu}$-containing particles in the vadose zone were X-ray amorphous. Analyses

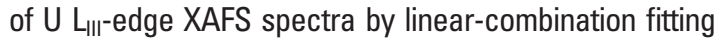
indicated that $U$ speciation consisted of (1) $\sim 75 \%$ uranyl sorbed to chlorite and $\sim 25 \%$ mtb-like X-ray amorphous U-Cuphosphates (8 ft depth), (2) nearly 100\% sorbed uranyl (12 ft depth), and (3) $70 \%$ uranyl sorbed to chlorite and $\sim 30 \% \mathrm{cps} /$

\footnotetext{
* Corresponding author e-mail: dmsinger@berkeley.edu.

† Stanford University.

‡ Pacific Northwest National Laboratory.

$\$$ Stanford Synchrotron Radiation Lightsource.

"Current address: Department of Earth and Planetary Science, University of California - Berkeley, Berkeley, CA 94720.
}

mtb (groundwater zone). These findings suggest that dissolution of $\mathrm{U}(\mathrm{VI})-\mathrm{Cu}(\mathrm{II})$-bearing solids as well as desorption of $\mathrm{U}(\mathrm{VI})$, mainly from phyllosilicates, are important persistent sources of $\mathrm{U}(\mathrm{VI})$ to the associated uranium groundwater plume in Hanford Area 300.

\section{Introduction}

The Hanford site in Washington State was a location of plutonium production for nuclear weapons during World War II and the Cold War. These production activities resulted in the generation of nuclear wastes of different types and compositions. Low-activity wastes were disposed to the vadose zone in ponds, cribs, and trenches, whereas highactivity wastes were stored in underground tanks for later treatment that has not yet occurred. Widespread vadose zone disposal combined with leakage from storage tanks over the 69 years of site operation have resulted in a significant legacy of environmental contamination including waste plumes in both the vadose zone and groundwater $(1-3)$. These contaminated sites are currently being remediated in one of the world's largest environmental remediation activities.

One important site is the North and South 300 Area Process Pond complex (300-FF-5) at the south end of Hanford, where uranium (U)-contaminated groundwater discharges to the Columbia River (4). The process pond complex lies approximately $200 \mathrm{~m}$ west of the Columbia River shoreline and received Hanford's second largest inventory of disposed U $(46000 \mathrm{~kg}$ ) (3) primarily in the form of acidic fuel rod fabrication waste solutions containing $\mathrm{U}(\mathrm{VI})-\mathrm{Cu}(\mathrm{II})$ from 1943 to 1974 . The two ponds also received approximately $238000 \mathrm{~kg}$ of $\mathrm{Cu}, 1156000 \mathrm{~kg}$ of F${ }^{-}, 243000 \mathrm{~kg}^{-}$of $\mathrm{NO}_{3}{ }^{-}$, large of amounts of $\mathrm{Al}$ (as $\mathrm{Al}(\mathrm{OH})_{4}^{-}$), and smaller undocumented amounts of $\mathrm{Ni}, \mathrm{Cr}, \mathrm{Zn}, \mathrm{Zr}$, and $\mathrm{P}$. Sodium hydroxide was frequently added to mitigate acidic $\mathrm{pH}$ and retard $\mathrm{Cu}$ and $\mathrm{U}$ migration through the vadose zone and associated groundwater system (5). The $\mathrm{pH}$ of the pond waters varied between 1.8 and 11.4 during active use. The use of these ponds for waste disposal has resulted in a persistent $\mathrm{U}(\mathrm{VI})$ groundwater plume (5).

Previous research has found that $U$ speciation in the Hanford 300 Area vadose zone includes uranyl sorbed to a complex phyllosilicate suite of minerals and the U(VI) $-\mathrm{Cu}(\mathrm{II})$ phosphate mineral metatorbernite $(6,7)$. Limited measurements suggest that $U$ speciation in the groundwater zone is dominated by adsorption to phyllosilicates (6). The implication of these results is that release of $U$ from the vadose zone to the groundwater zone is likely dominated by a combination of desorption and dissolution processes. However, the longevity of the 300 Area groundwater U(VI) plume is unexpected given the large flux of groundwater that has passed through the aquifer. Further investigation is needed to determine the processes that control the release of $U$ from the lower vadose zone to groundwater, and the dominant forms of $U$ in the aquifer sediments. While groundwater $U$ concentrations range from 5 to $150 \mathrm{ppb}$, solid-phase $U$ concentrations in aquifer fines (silt and clay) that represent $<2 \%$ of the total sediment by mass can reach $250 \mathrm{ppm}$ in the most extreme case. Therefore, precipitated $U$ phases may be present that can serve as long-term sources to groundwater that discharges into the Columbia River.

We have determined the molecular-level speciation and distribution of $U$ in contaminated sediments from the 300 Area North Process Pond \# 2 (NPP2) to serve as a basis for accurate predictive models for the resupply of contaminant $\mathrm{U}$ to this persistent plume (e.g., ref 8 ). The excavation studied 
TABLE 1. A Summary of U Speciation and Distribution Data for NPP2 Sediments Based on XMP and XAS Analyses

\begin{tabular}{|c|c|c|c|c|}
\hline \multirow[b]{2}{*}{ depth } & \multicolumn{2}{|c|}{ U oxidation state } & \multicolumn{2}{|c|}{ U-bearing and/or U-associated phases ${ }^{a}$} \\
\hline & $\begin{array}{c}\text { bulk } \\
\text { XANES }^{b}\end{array}$ & $\mu$ XANES $^{c}$ & $\begin{array}{l}\text { low to med. } \\
\text { U XRF counts }\end{array}$ & $\begin{array}{c}\text { high U } \\
\text { XRF counts }\end{array}$ \\
\hline $\begin{array}{l}8^{\prime} \\
12^{\prime}\end{array}$ & $\begin{array}{l}>95 \% \text { U(VI) } \\
>95 \% \text { U(VI) }\end{array}$ & $\begin{array}{l}>90 \% \text { U(VI) } \\
>90 \% \text { U(VI) }\end{array}$ & $\begin{array}{l}\text { chlorite, magnetite } \\
\text { chlorite }\end{array}$ & $\begin{array}{l}\text { chlorite, amorphous } \mathrm{U}-\mathrm{Cu} \text { hotspots } \\
\text { chlorite, muscovite, cuprosklodowskite, }\end{array}$ \\
\hline GW & $>95 \% \mathrm{U}(\mathrm{VI})$ & $>90 \% \mathrm{U}(\mathrm{VI})$ & chlorite & metatorbernite, amorphous U-Cu hotspots \\
\hline
\end{tabular}

(NPP2) was the only one of four opened in May 2003 (5) that has provided samples with sufficient $U$ concentrations for XAFS analyses $(6,7)$. A full accounting of the mineralogical association of the adsorbed/precipitated U inventory in these samples has not been achieved because of sample complexity (cf., ref 7.). The present study builds on recent chemical and mineralogical analyses of 300 Area Processing Pond samples $(6,7,9,10)$ and characterizes the dominant U-bearing and/ or U-associated phases and how they change with depth from the vadose to groundwater zones using synchrotronbased X-ray fluorescence imaging, X-ray absorption fine structure (XAFS) spectroscopy, and X-ray diffraction techniques. These analyses provide insights on plausible geochemical processes that occurred at the time of waste disposal and others that now control U-fluxes to and within the saturated zone.

\section{Materials and Methods}

Sediment Collection and Preparation. Contaminated vadose zone and aquifer sediments from the Hanford 300 Area were collected from one (NPP2) of four vertical excavations in the 300 Area Processing Pond complex. Vadose zone sediment samples were collected at $8 \mathrm{ft}(2.4 \mathrm{~m})$ depth and $12 \mathrm{ft}(3.7 \mathrm{~m})$ depth and were labeled NPP2-8' and NPP2-12', respectively. The aquifer materials (groundwater fines, NPP2-GW) were isolated by filtration of turbid groundwaters that rapidly drained into the excavation below the water table $16 \mathrm{ft}$ (4.9 $\mathrm{m})$. The groundwater fines represented silt- and clay-sized materials that were washed from coarse-textured, transmissive aquifer sediments exposed and disturbed by excavation. The sediments were dry-sieved to yield a $<2.0 \mathrm{~mm}$ size fraction for more detailed chemical and mineralogical study of the reactive components. The solid-phase U concentration (for the $<2 \mathrm{~mm}$ fraction) was determined by digesting sediment samples in $0.5 \mathrm{M}$ nitric acid for $48 \mathrm{~h}$ and analyzing the extract with a kinetic phosphorescence analyzer (KPA). The $\mathrm{U}$ concentrations for the three samples were $144 \mathrm{ppm}$ (NPP2-8'), 70 ppm (NPP2-12'), and 200 ppm (NPP2-GW). Further information regarding local lithology, sediment collection, and other analyses can be found in Qafoku et al. (10), Catalano et al. (6), Zachara et al. (2, 5), Bond et al. (11), and Stubbs et al. (12). Thin-sections were prepared for all three sediment samples as described by Liu et al. (13).

Synchrotron $\boldsymbol{\mu X}$-ray Fluorescence Imaging. $\mu \mathrm{XRF}$ imaging was performed on beamline 13-ID-C (GSECARS) at the Advanced Photon Source. The incident X-ray beam was focused using a pair of Kirkpatrick-Baez mirrors, and the incident beam was monochromatized using a Si(111) doublecrystal monochromator. $\mu \mathrm{XRF}$ maps and $\mu \mathrm{X}$-ray absorption near edge structure ( $\mu$ XANES) spectra were collected using either a Vortex single-element or a four-element solid-state silicon detector (SII NanoTechnology USA Inc., Northridge, CA). For $\mu$ XRF mapping, the incident beam was set at $20 \mathrm{keV}$ and focused to a $3 \mu \mathrm{m}$ spot size. $\mu$ XRF maps were obtained by rastering the beam at $3 \mu \mathrm{m}$ steps, with a count time of $0.5 \mathrm{~s}$ per step, for the following major and minor/trace elements: K, Ca, Ti, V, Cr, Mn, Fe, Ni, Cu, Zn, As, Se, Rb, U, $\mathrm{Sr}$, and Zr. Energy calibration of the $\mu$ XANES was performed with a yttrium foil, with the first inflection point of the yttrium K-edge being set to $17,038 \mathrm{eV}$. Results of bulk U L $\mathrm{L}_{\text {III }}$-edge EXAFS spectroscopy measurements are presented in the Supporting Information. $\mu \mathrm{XRD}$ patterns were collected on selected areas in transmission geometry using a MarCCD camera (Mar USA, Evanston, IL) with the incident beam energy set at $20 \mathrm{keV}(\lambda=0.6200 \AA)$. The resulting images were processed with FIT2D (14). The sample-to-detector distance and geometric corrections were calculated using $\mathrm{CeO}_{2}$ as a standard. After these corrections were applied, the $2 \mathrm{D}$ images were integrated radially to yield $1 \mathrm{D}$ diffraction patterns that could then be analyzed using standard techniques. Background subtraction, including removal of the scattering from the glass slide, and phase identification were performed using JADE 6.5 (Materials Data Inc., Livermore, CA).

\section{Results and Discussion}

Uranium Distribution and Associated Elements and Minerals. Two populations of $\mathrm{U}$ were defined in the $\mu \mathrm{XRF}$ imaging based on XRF count rate (Table 1). Although it is difficult to translate XRF count rate into absolute element concentration because of matrix effects, these count rate ranges were useful in classifying $U$ speciation within the NPP2 sediments. The $\mu \mathrm{XRF}$ maps presented in Figure 1 are representative of the distributions of $U$ and Cu observed in all three samples. $\mu$ XRD patterns (Figure 2) from selected areas not necessarily present in the $\mu$ XRF maps reveal the presence of major silicate and minor U-bearing crystalline phases, which are listed in Table 1. One additional $\mu$ XRF analysis is shown in the Supporting Information Figure S1.

$\boldsymbol{\mu} \mathrm{XRF}$ and $\boldsymbol{\mu} \mathrm{XRD}$ Results for Sample NPP2-8'. $\mu \mathrm{XRF}$ imaging indicated that $\mathrm{U}$ and $\mathrm{Cu}$ in the NPP2-8' sample exhibited low to moderate concentrations that were spatially correlated with fine-textured grain coatings (Figure 1A). These grain coatings are likely authigenic (i.e., resulting from wastesediment interactions) hence the spatial correlation between the grain coatings and $\mathrm{U}$ and $\mathrm{Cu}$. The characteristic $d$-spacing observed in the $\mu$ XRD patterns (Figure 2) allowed for differentiation between clay minerals and other sheetsilicates potentially present in the sediment; however, poorly crystalline solids or minerals with grain sizes less than approximately $1 \mu \mathrm{m}$ would be difficult to detect by this technique. In sample NPP2-8', the crystalline component of these grain coatings were consistently found to contain chlorite throughout the sample (Figure 2). Although chlorite is an accessory mineral in these sediments (10), it was commonly observed in association with feldspar as intergrowths and surface deposits. Cu was also strongly correlated with these same chlorite domains. Although the spatial distribution of $\mathrm{Cu}$ was not identical to that of $\mathrm{U}$, the highest $\mathrm{Cu}$ concentrations were correlated with the highest $\mathrm{U}$ concentrations in the thin sections examined. In one occurrence, low concentrations of $\mathrm{U}$ and $\mathrm{Cu}$ were also 



B. NPP2-12'


C. NPP2-GW
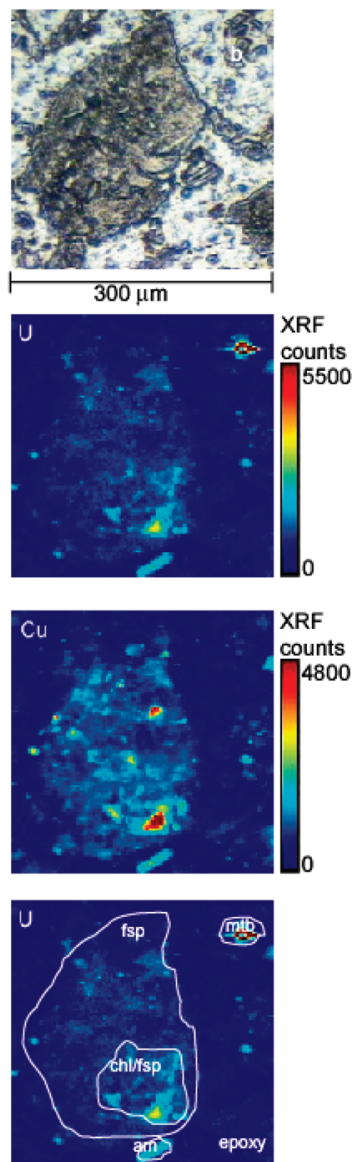

FIGURE 1. Representative reflected light images and $\mu$ XRF $U$ L $\alpha$ and $\mathrm{Cu} K \alpha$ maps of Hanford 300 Area NPP2 sediments. Grains boundaries on the $U$ map are outlined in white based on the reflected light images, and the mineral phase identification is based on the $\mu$ XRD patterns. The phases present are quartz (qtz), chlorite (chl), feldspar (fsp), metatorbernite (mtb), amorphous phases (am), and epoxy. The letters on the reflected light image ( $b$ and e) correspond to the location of $\mu$ XRD patterns presented in Figure 2.

spatially correlated with a grain of magnetite, which is also an accessory mineral in these sediments. The $\mathrm{U}-\mathrm{Cu}$-chlorite correlations were not associated with any of the other elements detected by the $\mu \mathrm{XRF}$ analyses.

High U concentrations spatially correlated with high $\mathrm{Cu}$ concentrations were also observed, occurring both as hotspots associated with chlorite and as independent grains separated from the larger mineral clasts within the epoxy. $\mathrm{Cu}$ hotspots were spatially correlated with $\mathrm{U}$; no U-free, $\mathrm{Cu}-$ hotspots were observed. The U-Cu-hotspots were on the order of $10-50 \mu \mathrm{m}$ in diameter and were not highly correlated with any of the other elements detected. The $\mu \mathrm{XRD}$ patterns indicated that these $\mathrm{U}-\mathrm{Cu}$-hotspots were $\mathrm{X}$-ray amorphous, and the high XRF counts indicated that $\mathrm{U}$ and $\mathrm{Cu}$ occurred as major elements within these grains. Although metatorbernite has been previously reported at one intermediate depth within the 300 Area vadose zone $(6,7)$, neither $\mu$ XRF imaging nor electron microprobe analysis could positively identify these grains as phosphate-bearing phases, as phosphorus could not be detected. Imaging Si and P, was not feasible under the experimental conditions because their fluorescence signal was overwhelmed by the Fe K $\alpha$ signal. $\mu$ XRF mapping below the Fe K $\alpha$ energy was also unsuccessful because the detector resolution was not good enough to differentiate $\mathrm{Si}$ from P. Although electron microprobe analysis (EMPA) can easily differentiate $\mathrm{Si} K \alpha$ from $\mathrm{P}$ K $\alpha$ fluorescence signals, the penetration depth of a $20 \mathrm{keV}$ electron beam is approximately $1 \mu \mathrm{m}$ (15), whereas the X-ray absorption length is greater than the thickness of the sample $(50 \mu \mathrm{m})$ for the synchrotron experiments (16). As a result, U-bearing grains that are embedded in the sample more deeply than approximately
$1 \mu \mathrm{m}$ would not be detected by EMPA, and therefore differentiation between a Si- or P-bearing phase in our samples was not feasible. Bulk $\mathrm{U}_{\mathrm{III}}$-edge EXAFS spectroscopy, discussed below, was used to determine which $U$ bearing and/or U-associated phases dominate $U$ speciation and their relative proportions.

$\boldsymbol{\mu}$ XRF and $\boldsymbol{\mu}$ XRD Results for Sample NPP2-12'. The $\mu$ XRF analyses of sample NPP2-12' indicated that sorbed U was present in low concentrations (consistent with the low total $\mathrm{U}$ concentration in the sample of $70 \mathrm{ppm}$ ) and is spatially correlated with $\mathrm{Cu}$ and in surface coatings that contained chlorite (Figure 1B). No U-Cu-bearing hotspots were observed in this sample. Based on reflected light microscopy, mineral modal abundances (determined by a "point-count" method that involved taking a random-walk path around the sample) and grain morphologies were the same at the 8 and $12 \mathrm{ft}$ depths, and it is therefore unlikely that the change in $U$ distribution is due to differences in sediment mineralogy. We speculate that speciation and $U$-concentration differences between NPP2-8' and NPP2-12' were a result of site heterogeneity rather than chromatographic reactive transport. $\mathrm{U}-\mathrm{Cu}$-bearing zones were visually evident during sampling as irregular "tongues" of green-colored sediment (5).

$\boldsymbol{\mu}$ XRF and $\boldsymbol{\mu}$ XRD Results for Sample NPP2-GW. The $\mu$ XRF results for sample NPP2-GW were similar to those of sample NPP2-8' with respect to $U$ occurrence and relative distribution. Areas of low to moderate U concentrations were spatially correlated with areas of moderate $\mathrm{Cu}$ concentrations and fine-textured grain coatings that were consistently found to contain chlorite, based on $\mu$ XRD patterns collected within the grain coatings (Figure 1C). The chlorite in the groundwater 

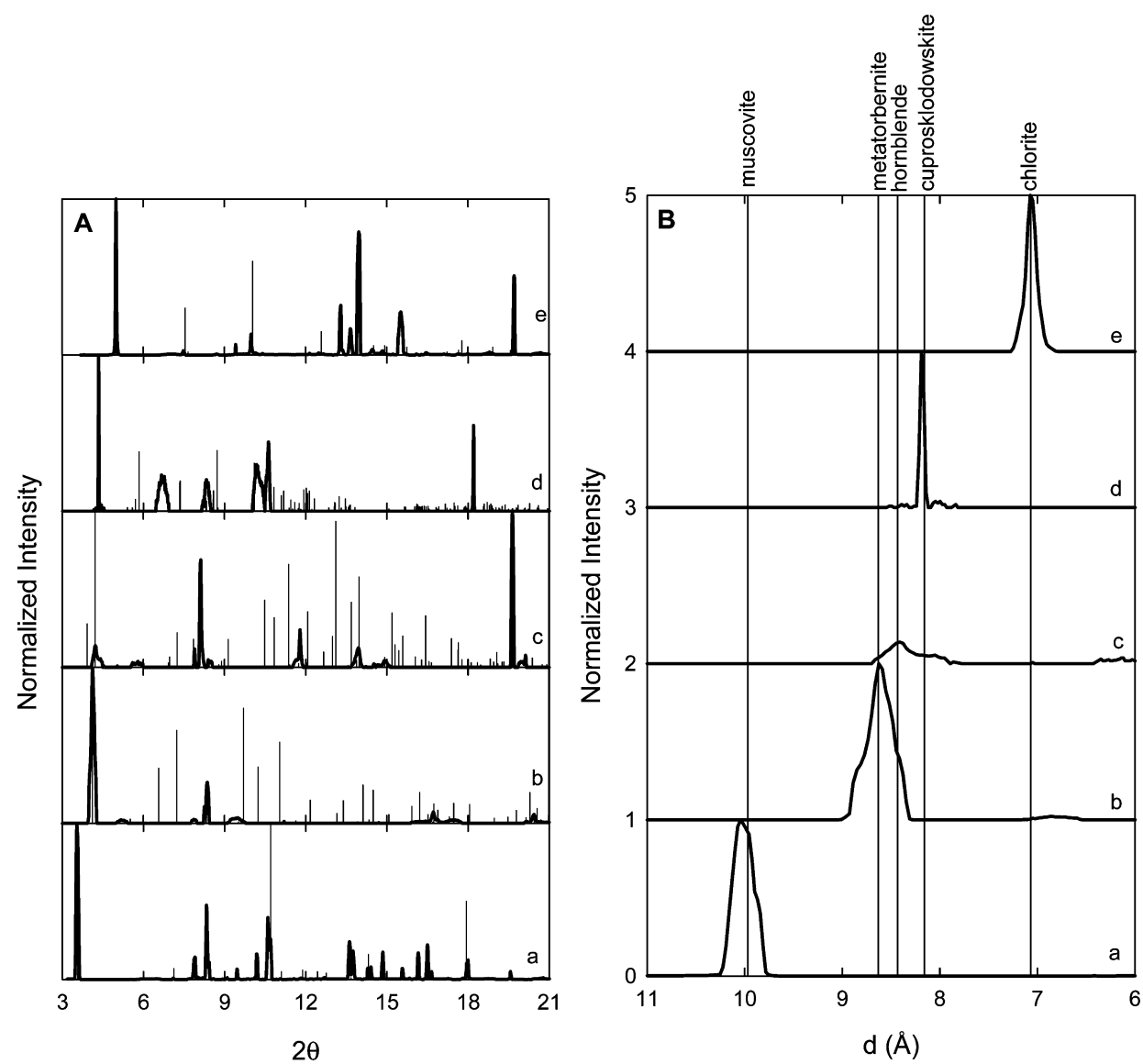

FIGURE 2. (A) Radially integrated and background-subtracted $\mu$ XRD patterns of selected spots (black patterns; a-e) from the Hanford 300 Area NPP2 sediments and ICSD patterns (gray) corresponding to the identified minerals, and (B) $\mu$ XRD patterns of the same spots plotted versus $d$ spacing for the region of the most intense lines of muscovite (ICSD no. 07-0042), metatorbernite (ICSD no. 60-7634), hornblende (ICSD no. 64-2144), cuprosklodowskite (ICSD no. 60-2493), and chlorite (clinochlore) (ICSD no. 29-0701). The $\mu$ XRD patterns were collected from samples NPP2-8' (patterns c and e) and NPP2-GW (patterns a, b, and d). Not all $\mu$ XRF images containing the locations of the $\mu$ XRD patterns could be presented; the locations of the $\mu$ XRD patterns for spots $b$ and $e$ are shown in the $\mu \mathrm{XRF}$ maps in Figure 1.

fines tended to occur mostly as intergrowths within larger feldspar grains.

A key distinction between samples NPP2-GW and NPP28' was the presence of crystalline $\mathrm{U}-\mathrm{Cu}$-bearing phases in the aquifer fines. These phases were identified as cuprosklodowskite (Supporting Information Figure S1) and metatorbernite (Figure 1) based on their $\mu \mathrm{XRD}$ patterns (Figure 2 ). The presence of cuprosklodowskite in the Hanford 300 Area sediments is a novel result, and the implications of its occurrence will be discussed below. Metatorbernite was observed as discrete grains, approximately $20-50 \mu \mathrm{m}$ in size, that were not associated with the major mineral clasts. This observation contrasts with previous analyses that revealed metatorbernite within authigenic aluminosilicate grain coatings resulting from waste fluid-sediment reactions (7). These grain coatings have been qualitatively observed to decrease in thickness and extent with depth beneath the process ponds as the waste solutions were neutralized through geochemical reactions $(5,17)$. The dispersed state of the metatorbernite precipitates observed in NPP2-GW is therefore consistent with their formation in groundwater through homogeneous or heterogeneous precipitation. There is no evidence for colloid-associated migration of $\mathrm{U}$ or $\mathrm{Cu}$ through the NPP vadose zone, but conditions can be envisioned during and after the disposal period, or even during sampling, that may have encouraged this transport vector.

The $\mathrm{U}-\mathrm{Cu}$-bearing hotspots in the $\mu \mathrm{XRF}$ maps identified as cuprosklodowskite by $\mu$ XRD were approximately $30 \mu \mathrm{m}$ in size and were spatially correlated with muscovite (Sup- porting Information Figure S1) and chlorite. X-ray amorphous $\mathrm{U}-\mathrm{Cu}$-bearing phases were also observed in sample NPP2GW, and the high $U$ and $\mathrm{Cu}$ XRF count rate from these hotspots again suggest that $\mathrm{U}$ and $\mathrm{Cu}$ are major elements within these phases. Identification of these grains as either a silicate or a phosphate phase could not be determined by $\mu \mathrm{XRF}$ and electron microprobe analyses.

Uranium Speciation Based on Bulk $U \mathrm{~L}_{\mathrm{III}}$-edge EXAFS Spectroscopy. Bulk U L LII-edge EXAFS spectra of the sediments were collected to quantify the relative contribution of the two main types of uranyl species in the Hanford Area 300 NPP2 sediments (Table 1; see the Supporting Information for details).

Bulk EXAFS Results for Sample NPP2-8'. U $\mathrm{L}_{\mathrm{III}}$-edge EXAFS spectra are sensitive to structural differences between groups of uranyl minerals (e.g., uranophane versus autunite group minerals), but not necessarily within a group (e.g., meta-autunite versus metatorbernite) (18). It is therefore reasonable to use species from different groups (cuprosklodowskite and metatorbernite) as components in the fitting protocol with confidence that statistically significant changes in the contribution of each component are meaningful. The two best fits of the spectra for sample NPP2-8' were (1) $68 \%$ uranyl sorbed on chlorite, $25 \%$ metatorbernite, and $6 \%$ cuprosklodowskite, and (2) $74 \%$ uranyl sorbed to chlorite and 25\% metatorbernite (Figure 3, Table 2). Although the reduced chi-squared value of the fit using the first set of components (0.67) was slightly better than the fit using the second set (0.70), given a fitting error of $\pm 5 \%$ for each 


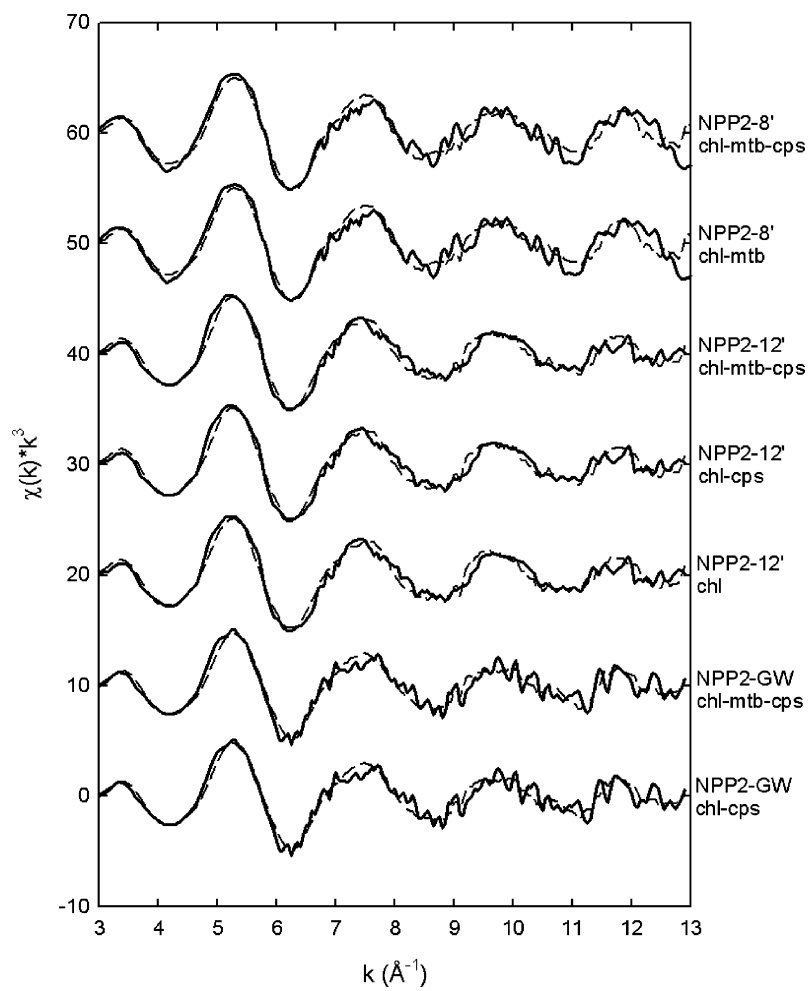

FIGURE 3. Best fit results (dashed lines) by least-squares linear combination Fitting of the bulk $U \mathrm{~L}_{111}$-edge EXAFS spectra (solid lines) of the Hanford 300 Area NPP2 sediments samples. The best-fit components are listed for each spectrum are uranyl sorbed to chlorite (chl), cuprosklodowskite (cps), and metatorbernite $(\mathrm{mtb})$. Tabulated best fit results are presented in Table 2

component, it seems unlikely that cuprosklodowskite contributed significantly to the signal in the EXAFS spectrum of sample NPP2-8'. Uranyl sorbed on chlorite yields a significantly better fit ( $>10 \%$ decrease in the reduced chi squared value) than uranyl sorbed on montmorillonite at similar solution conditions (data not included in Table 2). Although a better fit of the sample spectrum with $U(V I)$ sorbed on chlorite versus montmorillonite is not direct proof that chlorite is the actual sorbent in the natural material, this result is reasonable given that chlorite was identified by $\mu$ XRD in the fine-textured surface coatings with which $\mathrm{U}(\mathrm{VI})$ was spatially correlated. No such spatial correlations were observed for montmorillonite. The $\mathrm{UL}_{\mathrm{III}}$-edge EXAFS spectra of uranyl sorbed on chlorite and montmorillonite are different, particularly with respect to the second-shell coordination environment $(19,20)$. It is not clear whether these differences are significant enough to yield statistically different fits using linear-combination fitting (LCF) of multicomponent U-bearing natural samples. However, as the $\mu \mathrm{XRF}$ imaging and $\mu \mathrm{XRD}$ patterns indicate that chlorite is the dominant crystalline layer-silicate mineral with particle sizes greater than $1 \mu \mathrm{m}$ with which $\mathrm{U}(\mathrm{VI})$ is associated, the choice of chlorite rather than montmorillonite as the sorbent of $U(V I)$ in the linear-combination fitting is reasonable. The fit results for the NPP2-8' U EXAFS spectrum are consistent with the $\mu \mathrm{XRF}$ imaging: $\mathrm{U}$ speciation and distribution are dominated by uranyl associated with chlorite, with a fraction of the $\mathrm{U}$ associated with $\mathrm{U}-\mathrm{Cu}$-bearing precipitates. The $\mu$ XRD patterns of the $\mathrm{U}-\mathrm{Cu}$-hotspots showed them to be $\mathrm{X}$-ray amorphous, and thus they are not metatorbernite. However, assuming the X-ray amorphous $\mathrm{U}-\mathrm{Cu}$-hotspots have compositions qualitatively similar to their crystalline counterparts, it is reasonable to expect that the bulk $\mathrm{U} \mathrm{L} \mathrm{LII-}^{-}$ EXAFS spectra of the amorphous and crystalline phases to
TABLE 2. Best Fit Results of the Bulk U L L-edge EXAFS Spectra of the Hanford 300 Area NPP2 Sediments ${ }^{a}$

$\begin{array}{ccccc}\begin{array}{c}\text { sample } \\ \text { depth (ft) }\end{array} & \text { component } & \begin{array}{c}\text { component } \\ \text { fraction } \\ \text { (from fit) }\end{array} & \begin{array}{c}\text { component } \\ \text { sum }\end{array} & \begin{array}{c}\text { reduced } \\ \chi^{2}\end{array} \\ 8 & \text { chl } & 0.68 & 0.99 & 0.67 \\ & \mathrm{mtb} & 0.25 & & \\ 8 & \mathrm{cps} & 0.06 & & \\ & \mathrm{chl} & 0.74 & 0.99 & 0.70 \\ 12 & \mathrm{mtb} & 0.25 & & \\ & \mathrm{chl} & 0.78 & 1.01 & 0.35 \\ & \mathrm{mtb} & 0.16 & & \\ 12 & \mathrm{cps} & 0.07 & & \\ & \mathrm{chl} & 0.87 & 1.01 & 0.35 \\ 12 & \mathrm{cps} & 0.14 & & \\ \mathrm{GW} & \mathrm{chl} & 0.99 & 0.99 & 0.38 \\ & \mathrm{chl} & 0.63 & 0.99 & 0.45 \\ & \mathrm{mtb} & 0.06 & & \\ \mathrm{GW} & \mathrm{cps} & 0.30 & & \\ & \mathrm{chl} & 0.71 & 0.99 & 0.44 \\ & \mathrm{cps} & 0.28 & & \end{array}$

${ }^{a}$ The components listed are uranyl sorbed on chlorite (chl), metatorbernite (mtb), and cuprosklodowskite (cps). Two fits for samples NPP2-8' and NPP2-GW were attempted, one with three components and one with two components, whereas three fits were attempted for sample NPP2-12', with three, two, and one component, respectively. The similarity of the reduced $\chi^{2}$ values of the various fits does not allow us to choose a best fit, based on this criterion alone. See Supporting Information Table S1 for all model and reference compounds used as components.

be similar $(18,21)$. Based on this reasoning, we choose to use the $\mathrm{U} \mathrm{L}_{\mathrm{III}}$-edge EXAFS spectrum of metatorbernite and cuprosklodowskite as fitting components in the LCF modeling reported in Table 2.

This choice of metatorbernite as a reference spectrum for the amorphous phase may be arguable because of the low phosphorus $(\mathrm{P})$ concentrations in the sediments $(\sim 2000 \mathrm{ppm})$ (6), and the current lack of direct detection of the phosphate oxoanion for any $\mathrm{U}-\mathrm{Cu}$-precipitates in sample NPP2-8'. Although it is possible that $\mathrm{Cu}(\mathrm{II})$-bearing phases such as $\mathrm{Cu}(\mathrm{OH})_{2}$ (spertiniite), $\mathrm{CuO}$ (tenorite), $\mathrm{Cu}_{2}(\mathrm{OH})_{2}\left(\mathrm{CO}_{3}\right)$ (malachite), or $\mathrm{Cu}_{3}(\mathrm{OH})_{2}\left(\mathrm{CO}_{3}\right)_{2}$ (azurite), which would be expected to form under oxidizing conditions (22) and could be present within the groundmass of $\mathrm{U}-\mathrm{Cu}$-hotspots, none of these phases were observed in our samples based on the $\mu \mathrm{XRD}$ patterns. Further, the strong correlation of $\mathrm{U}$ and $\mathrm{Cu}$ in the hotspots found in the $\mu \mathrm{XRF}$ imaging suggests that at least a portion of these $\mathrm{U}-\mathrm{Cu}$-hotspots are $\mathrm{U}-\mathrm{Cu}$-bearing phases, and not discrete $\mathrm{Cu}$-bearing and U-bearing phases.

$\mathrm{U}-\mathrm{Cu}$-phosphates and -silicates are frequently observed to precipitate with other divalent metal-bearing U-containing phases in those series; for example, meta-autunite $(\mathrm{Ca}-\mathrm{U}$ phosphate) occurs with metatorbernite, and sklodowskite (Mg-U-silicate) occurs with cuprosklodowskite $(23,24)$. In the present study, only $\mathrm{Cu}$-containing uranyl phases were identified and no Ca- or Mg-uranyl phosphates or silicates were detected. Arai et al. (7) also observed no other U-phosphate phase such as autunite present in the vadose zone samples in which metatorbernite were found. This observation is consistent with metatorbernite and cuprosklodowskite being relict phases that formed by rapid precipitation when the $\mathrm{U}-\mathrm{Cu}$-bearing waste interacted with the 
sediments under historic conditions of higher aqueous $\mathrm{Cu}$ and $\mathrm{P}$ than are currently observed. These latter two solutes are generally below detection in current vadose zone pore waters and groundwater that are circumneutral in $\mathrm{pH}$, dominated by $\mathrm{Ca} / \mathrm{Mg}-\mathrm{HCO}_{3} / \mathrm{NO}_{3}$, and near equilibrium with amorphous silica because of copious basaltic lithic fragments in the sediments.

Bulk EXAFS Results for Sample NPP2-12'. We attempted several fits for sample NPP2-12' including the following fit components: (1) uranyl sorbed on chlorite, (2) uranyl sorbed on chlorite plus cuprosklodowskite, and (3) uranyl sorbed on chlorite, cuprosklodowskite, and metatorbernite (Figure 3 , Supporting Information Table S2). However, because the reduced $\chi^{2}$ values were statistically the same for these three fits, the one with the fewest components was chosen. These results suggest that $U$ speciation at this depth is dominated by adsorbed U(VI) on phyllosilicate edges, and that $\mathrm{U}-\mathrm{Cu}$-bearing precipitates are absent in this sample. These results are consistent with the $\mu \mathrm{XRF}$ imaging results of our sample from NPP2-12', which showed no $\mathrm{U}-\mathrm{Cu}$ hotspots.

Bulk EXAFS Results for Sample NPP2-GW. The two best fits of the EXAFS spectra of the groundwater fines consisted of the following components: (1) $71 \%$ uranyl sorbed to chlorite and $28 \%$ cuprosklodowskite, and (2) $63 \%$ uranyl sorbed to chlorite, $30 \%$ cuprosklodowskite, and $6 \%$ metatorbernite (Figure 3, Supporting Information Table S2). As was the case for sample NPP2-8', uranyl sorbed on chlorite as a fit component yielded a better fit than uranyl sorbed on montmorillonite for sample NPP2-GW. Given the error inherent in the LCF protocol, a $6 \%$ signal contribution from metatorbernite might be considered insignificant. However, as metatorbernite and cuprosklodowskite were identified by $\mu \mathrm{XRD}$ in sample NPP2-GW, it is reasonable to include both in the LCF model. Therefore, the combination of $\mu \mathrm{XRD}$ and EXAFS-LCF analyses of sample NPP2-GW indicates that U speciation in the groundwater zone is dominated by uranyl sorbed to chlorite, with a sizable fraction of the U(VI) (up to $30 \%$ ) present as cuprosklodowskite and a minor fraction present as metatorbernite.

Release of Uranium from NPP2 Sediments. Due to the complex and likely varied geochemistry of the U-bearing waste and neutralized fluids that the NPP2 sediments were exposed to, it is difficult to constrain the reaction network that controlled $U$ sorption and (co)precipitation during Process Pond operation (Supporting Information). However, predicting the release of U from the NPP2 sediments is dependent on understanding the current $U$ speciation as revealed here, and the degree of contact of these species with mobile pore fluids.

The results presented here refine and extend earlier work on Hanford 300 Area vadose zone sediments; U speciation is dominated by uranyl associated with fine-textured grain coatings that were consistently found to contain chlorite. Sorbed U(VI) within intragrain domains, e.g., of both chlorite and lithic fragments, may explain its slow rate of desorption or dissolution $(10,25)$. However, $\mathrm{U}-\mathrm{Cu}$-bearing precipitates dominated by an amorphous $\mathrm{U}(\mathrm{VI})-\mathrm{Cu}(\mathrm{II})$-containing phase similar to metatorbernite (sample NPP2-8') accounts for $\sim 25-30 \%$ of the $U$ in localized vadose zone areas where high $\mathrm{U}-\mathrm{Cu}$-concentration fluids interacted with the sediments. This localized bimodal distribution of $U$ was also observed for one (NPP2-GW) of four aquifer fines samples collected from near the water table, where U speciation was dominated by sorption to chlorite with associated cuprosklodowskite precipitation. The absence of Ca analogues of both cuprosklodowskite and metatorbernite in the aquifer fines indicates that these phases are relatively stable under current groundwater conditions.
Our finding of amorphous $\mathrm{U}-\mathrm{Cu}$-containing solids in vadose zone sediments is potentially significant in this context because amorphous solids are generally more soluble than crystalline solids of similar compositions (26). Further, the $\mu \mathrm{XRF}$ imaging and bulk $\mathrm{U}_{\mathrm{III}}$-edge EXAFS analysis indicate that the precipitates are dominated by $\mathrm{U}-\mathrm{Cu}$-phosphates in the vadose zone, and by $\mathrm{U}-\mathrm{Cu}$-silicates in the groundwater zone. These different precipitated forms may result from the low overall concentration of phosphate in this system and its appreciable reactivity in transport through the vadose zone, even at historic acidic $\mathrm{pH}$ values. However, the bulk of the $U$ inventory in the Hanford 300 Area sediments is dominated by sorbed uranyl, as was observed in the NPP2$12^{\prime}$ sample. Transport of $U$ in these areas will therefore be dominated by desorption processes. Further leaching studies like those performed on the vadose zone sediments (11) are needed to determine the ease of dissolution of U-bearing precipitates in zones of high $U$ concentrations, whether dissolution or desorption processes dominate uranyl release from the groundwater zone sediments, and the time scales for expected release by these processes.

\section{Acknowledgments}

This research was supported by the U.S. DOE Office of Biological and Environmental Research Environmental Remediation Science Program (ERSP) though DOE-ERSP grants FG07-ER0263495 and FG07-99ER15022 and in part by the Stanford Environmental Molecular Science Institute through NSF Grant CHE-0431425. Contaminated samples from the Hanford 300 Area were collected and chemically and mineralogically characterized by the Hanford Remediation and Closure Science Project. We thank C. Tom Resch (PNNL) for uranium KPA values. We thank John Bargar (SSRL), Joe Rogers (SSRL), and Matt Newville (GSECARS) for their beamline support during data collection, and François Farges (Muséum National d'Histoire Naturelle, Paris, France) for assistance during bulk EXAFS spectroscopy data collection. Comments from three anonymous reviewers improved this manuscript. SSRL and APS are national user facilities supported by the DOE Office of Basic Energy Sciences (DOE-BES). GSECARS is supported by the National Science Foundation-Earth Sciences (EAR-0217473), DOE-Geosciences (DE-FG0294ER14466), and the State of Illinois. SSRL is operated by Stanford University on behalf of the U.S. DOE-BES.

\section{Supporting Information Available}

Additional text, figures, and tables including details of bulk EXAFS data collection, bulk- and $\mu$ XANES spectroscopy results and discussion, a discussion of the factors controlling uranium sorption and (co)precipitation in the Hanford 300 Area sediments, and an additional $\mu \mathrm{XRF}$ analysis. This material is available free of charge via the Internet at http:// pubs.acs.org.

\section{Literature Cited}

(1) Zachara, J. M.; Serne, J.; Freshley, M.; Mann, F.; Anderson, F.; Wood, M.; Jones, T.; Myers, D. Geochemical processes controlling migration of tank wastes in Hanford's vadose zone. Vadose Zone J. 2007, 6, 985-1003.

(2) Zachara, J. M.; Brown, C. F.; Christensen, J. N.; Davis, J. A.; Dresel, P. E.; Liu, C.; Kelly, S. D.; McKinley, J. P.; Serne, J.; Um, W. A site-wide perspective on uranium geochemistry at the Hanford Site, PNNL-17031; Pacific Northwest National Laboratory: Richland, WA, 2007.

(3) Hartman, M. J.; Morasch, L. F.; Webber, W. D. Hanford site groundwater monitoring for fiscal year 2006, PNNL-16346; Pacific Northwest National Laboratory: Richland, WA, 2007.

(4) Williams, B. A.; Brown, C. F.; Um, W.; Nimmons, M. J.; Peterson, R. E.; Bjornstad, B. N.; Lanigan, D. C.; Serne, R. J.; Spane, F. A.; Rockhold, M. L. Limited field investigation report for uranium 
contamination in the 300 Area, 300-FF-5 operable unit, Hanford Site, Washington, PNNL-16435; Pacific Northwest National Laboratory: Richland, WA, 2007.

(5) Zachara, J. M.; Davis, J. A.; Liu, C.; McKinley, J. P.; Qafoku, N. P.; Wellman, D. M.; Yabusaki, S. B. Uranium geochemistry in vadose zone and aquifer sediments from the 300 Area uranium plume, PNNL-15121; Pacific Northwest National Laboratory: Richmond, WA, 2005.

(6) Catalano, J. G.; McKinley, J. P.; Zachara, J. M.; Heald, S. M.; Smith, S. C.; Brown, G. E., Jr. Changes in uranium speciation through a depth sequence of contaminated Hanford sediments. Environ. Sci. Technol. 2006, 40, 2517-2524.

(7) Arai, Y.; Marcus, M. A.; Tamura, N.; Davis, J. A.; Zachara, J. M. Spectroscopic evidence for uranium bearing precipitates in vadose zone sediments at the Hanford 300-Area site. Environ. Sci. Technol. 2007, 41, 4633-4639.

(8) Davis, J. A.; Yabusaki, S. B.; Steefel, C. I.; Zachara, J. M.; Curtis, G. P.; Redden, G. D.; Criscenti, L. J.; Honeyman, B. D. Assessing conceptual models for subsurface reactive transport of inorganic contaminants. EOS Trans. Am. Geophys. Union 2004, $85,449$.

(9) Serne, R. J.; Brown, C. F.; Schaef, H. T.; Pierce, E. M.; Lindberg, M. J.; Wang, Z.; Gassman, P. L.; Catalano, J. G. 300 Area uranium leach and adsorption project, PNNL-14022; Pacific Northwest National Laboratory: Richland, WA, 2002.

(10) Qafoku, N. P.; Zachara, J. M.; Liu, C.; Gassman, P. L.; Qafoku, O., S.; Smith, S. C. Kinetic desorption and sorption of U(VI) during reactive transport in a contaminated Hanford sediment. Environ. Sci. Technol. 2005, 39, 3157-3165.

(11) Bond, D. L.; Davis, J. A.; Zachara, J. M. Uranium(VI) release from contaminated vadose zone sediments: Estimation of potential contributions from dissolution and desorption In Adsorption of Metals by Geomedia II; Barnett, M. O., Kent, D. B., Eds.; Academic Press: San Diego, CA, 2007; pp 379-420.

(12) Stubbs, J. E.; Veblen, L. A.; Elbert, D. C.; Zachara, J. M.; Davis, J. A., Veblen, D. R. Geochim. Cosmochim. Acta in press.

(13) Liu, C.; Zachara, J. M.; Qafoku, O.; McKinley, J. P.; Heald, S. M.; Wang, Z. Dissolution of uranyl microprecipitates in subsurface sediments at Hanford site, USA. Geochim. Cosmochim. Acta 2004, 68, 4519-4537.
(14) Hammersley, A. P. FIT2D: an Introduction and Overview; Internal Report ESRF97HA02; ESRF: Grenoble, France, 1997.

(15) Goldstein, J. I.; Newbury, D. E.; Echlin, P.; Joy, D. C.; Romig, J., A. D.; Lyman, C. E.; Fiori, C.; Lifshin, E. Scanning Electron Microscopy and X-ray Microanalysis; 2nd ed.; Plenum Publishing Corporation: New York, 1992.

(16) Elam, W. T.; Ravel, B. D.; Sieber, J. R. A new atomic database for X-ray spectroscopic calculations. Radiat. Phys. Chem. 2002, 63, 121-128.

(17) McKinley, J. P.; Zachara, J. M.; Wan, J.; McCready, D. E.; Heald, S. M. Vadose Zone J. 2007, 6, 1004-1017.

(18) Catalano, J. G.; Brown, G. E., Jr. Analysis of uranyl-bearing phases by EXAFS spectroscopy: Interferences, multiple scattering, accuracy of structural parameters, and spectral differences. Am. Mineral. 2004, 89, 1004-1021.

(19) Singer, D. M.; Maher, K.; Brown, G. E., Jr. Uranyl-chlorite sorption/desorption: Evaluation of different U(VI) sequestration processes. Geochim. Cosmochim. Acta,

(20) Catalano, J. G.; Brown, G. E., Jr. Uranyl adsorption onto montmorillonite: Evaluation of binding sites and carbonate complexation. Geochim. Cosmochim. Acta 2005, 69, 2995-3005.

(21) Farges, F.; Ponader, C. W.; Calas, G.; Brown, G. E., Jr. Structural environment of incompatible elements in silicate glass $/$ melt systems: II. $\mathrm{U}^{\mathrm{IV}}, \mathrm{U}^{\mathrm{V}}$, and $\mathrm{U}^{\mathrm{VI}}$. Geochim. Cosmochim. Acta 1992 , $56,4205-4220$.

(22) Flemming, C. A.; Trevors, J. T. Copper toxicity and chemistry in the environment: A review. Water, Air, Soil Pollut. 1989, 44, 143-158.

(23) Magalhaes, M. C. F.; Pedarosa de Jesus, J. D.; Williams, P. A. The chemistry of uranium dispersion in groundwaters at the Pinhal do Souto Mine, Portugal. Inorg. Chim. Acta 1985, 109, 71-78.

(24) Plášil, J.; Sejkora, J.; Ondruš, P.; Veselovsky, F.; Beran, P.; Goliáš, V. Supergene minerals in the Horni Slavkov uranium ore district, Czech Republic. J. Czech Geol. Soc. 2006, 5, 149-158.

(25) Liu, C.; Zachara, J. M.; Qafoku, N. P.; Wang, Z. Water Resour. Res. 2008, 44, W08413.

(26) Brantley, S. L. Kinetics of Mineral Dissolution In Kinetics of Water-Rock Interaction; Brantley, S. L., Kubicki, J. D., White, A. F., Eds.; Springer: New York, 2008; pp 151-210.

ES8021045 